\title{
Left Ventricular Apex Segment
}

National Cancer Institute

\section{Source}

National Cancer Institute. Left Ventricular Apex Segment. NCI Thesaurus. Code C127650.

The apical cap division of the left ventricular myocardium as determined using the AHA 17-Segment Model (Cerqueira et al., 2002). 